DR. ANGUS WEBB (Orcid ID : 0000-0003-0857-7878)

4

5

6

7

8

9

10

11

12 Jonathan Kennen ${ }^{1}$, Eric D. Stein ${ }^{2}$, J. Angus Webb ${ }^{3}$

$13{ }^{1}$ U.S. Geological Survey, 3450 Princeton Pike, Suite 110, Lawrenceville, NJ 08648, United States

14

15

16

17

18

19 Lawrenceville, NJ 08648, United States.

20

21

22

\section{Evaluating and Managing Environmental Water Regimes in a Water-Scarce and}

\section{Uncertain Future}

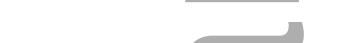

${ }^{2}$ Southern California Coastal Water Research Project, 3535 Harbor Blvd., Suite 110, Costa Mesa, CA 92626-1437, United States

${ }^{3}$ The University of Melbourne, Department of Infrastructure Engineering, Parkville 3010,

Australia

Correspondence: Jonathan G. Kennen, U.S. Geological Survey, 3450 Princeton Pike, Suite 110,

0 E-mail: jgkennen@usgs.gov

\section{ABSTRACT}

This is the author manuscript accepted for publication and has undergone full peer review but has not been through the copyediting, typesetting, pagination and proofreading process, which may lead to differences between this version and the Version of Record. Please cite this article as doi: $\underline{10.1111 / \text { fwb.13104 }}$

This article is protected by copyright. All rights reserved 
1. While the number of environmental flows and water science programs continues to grow across the globe, there remains a critical need to better balance water availability in support of human and ecological needs and to recognize the environment as a legitimate user of water. In water-stressed areas this recognition has resulted in friction between water users in the public and private sectors. An opportunity exists for practitioners to be on the forefront of the science determining best practices for supporting environmental water regimes.

2. This Special Issue brings together a collection of environmental flows science and water management papers organized around three major themes: 1 . Method development and testing; 2. Application case studies; and 3. Efficacy evaluation. Contents of this Special Issue are intended to foster collaboration and broaden transferability of the information, technical tools, models, and methods needed to support environmental water management programs.

3. The technical sophistication of methods and modelling tools, while important to the advancement of environmental water science, may come at the expense of easily interpretable outcomes that positively influence management decisions. Researchers need to be more proactive in translating the results of advanced modelling methodologies into user-friendly tools and methods. This will allow stakeholders and water managers to proactively test alternative water allocation scenarios to help address growing human water demands in the face of droughts and changes in climatic patterns.

4. The application of environmental flows science and water management strategies cannot be done in isolation. Implementation involves a complex decision-making process that integrates ecological, hydrologic and social science across diverse multifaceted governance systems and requires active stakeholder involvement. Scientists and managers must strengthen partnerships at multiple scales to develop sensible science investment strategies so that collective knowledge can be translated into wise environmental water management decisions. 
Key words: environmental flows science, environmental water management, modelling, ecohydrological investigations, case studies

\section{INTRODUCTION}

The tension between consumptive water use and ecological needs of rivers and estuaries has been a mainstay in the freshwater science literature for nearly 30 years. Over the years there have been synthesis articles, journal special issues and books devoted to various aspects of the science, implementation, and management of environmental flows to sustain species and ecosystems (Annear et al., 2004; Poff \& Zimmerman, 2010; Arthington, Naiman, McClain, \& Nilsson, 2010; Arthington, 2012; Hirji \& Davis, 2012; Kendy et al., 2012; Webb et al., 2013; Acreman et al., 2014; Richter, 2014; Novak et al., 2016; Horne, Webb, Stewardson, Richter, \& Acreman, 2017; Webb, Watts, Allan, \& Conallin, 2018). Despite this attention, growing water demands, coupled with recent droughts and changes in climatic patterns, have produced increasingly widespread water scarcity in many regions throughout the world (Meybeck, 2003; Trenberth, Overpeck, \& Solomon, 2004; Vörösmarty et al., 2010; Famiglietti et al., 2011; Estrela, Pérez-Martin, \& Vargas, 2012; Dettinger, Udall, \& Georgakakos, 2015; Veldkamp, Eisner, Wada, Aerts, \& Ward, 2015; Williams et al., 2015). These shortages emphasize that there are critical limits on the amount of water available to support human and ecological needs. These shortages have motivated many federal and provincial governments (Fig. 1a) to establish environmental flow rules and criteria (e.g., instream or minimum flow requirements) for the protection of biological resources and ecosystem integrity (Le Quense, Kendy, \& Weston, 2010; Hart, 2016; Novak et al., 2016). The cumulative number of programs establishing environmental flows and water management criteria in the US and across the globe has risen substantially just in the last decade (Fig. 1b), emphasizing the importance of retaining water in streams, rivers, estuaries and lentic systems for ecological use and ecosystem services. However, recognition of 'the environment' as a legitimate user of water has led to legal confrontations among water users in the public and private sectors (Poff et al., 2003; Capon \& Capon, 2017), and increased 
scrutiny of the methods used to determine, implement, and evaluate environmental water regimes.

82 Various approaches for assessing environmental flows and water regimes have been developed over the past two and half decades, including those based on species life-history requirements (e.g., instream flow incremental methods; Bovee et al., 1998), flows that determine requisite habitats (e.g., physical habitat simulations; Milhous, Updike, \& Schneider, 1989), holistic methods aimed at supporting biological communities and ecosystem functions (e.g., Ecological

87 Limits of Hydrologic Alteration, ELOHA: Poff et al., 2010), and targets based on deviation from unaltered hydrographs (e.g., presumptive standards approach, Richter, Davis, Apse, \& Konrad, 2011). Furthermore, the field of environmental flows is entering a transition phase from a focus on lotic waters to one that includes the water requirements of all freshwater bodies. Accommodating this important shift may require more flexible or new terminology as discussed in recent synthesis works (Horne et al., 2017; Arthington, Kennen, Stein, \& Webb, 2018). This means that environmental water assessment methods, as well as implementation approaches and strategies, can differ with waterbody type and across political jurisdictions, continents and even across individual basins that traverse multiple states, provinces or countries. These jurisdictional differences exacerbate the challenges of managing and regulating environmental water regimes.

Moreover, as technical sophistication in the methods used to assess and evaluate environmental water regimes increase, researchers need to be more proactive in translating the results of advanced modelling methodologies into user-friendly tools. These may include web-based applications and decision support systems that provide easily navigable graphical user interfaces, with options for flow scenario testing and insight into the effects of climate change or changes in water availability (e.g., Williamson et al., 2015; Cartwright, Caldwell, Nebiker, \& Knight, 2017). Such tools need to be adaptable to local conditions and needs, but also highly transferable across river basins or political jurisdictions, thus allowing the broader exchange of ecological and hydrologic / hydraulic information and models to support the 107 balancing of water management decisions for human and ecosystem needs. 
This Special Issue builds on previous work by providing broad example applications and case studies that illustrate implementation of ecohydrological approaches and provide empirical observations on the efficacy of these approaches. The previous Special Issue on "Environmental Flows: Science and Management" published in Freshwater Biology in 2010 strongly moved the field forward by introducing new methods and analytical techniques such as the ELOHA framework, ecological trait analysis, Bayesian hierarchical modelling, and Integrated Basin Flow Assessment (Arthington et al., 2010). In this Special Issue we continue that legacy by including studies from Australia, Europe, and North America that cover the development of novel technical tools, models, and methods necessary for implementation of environmental water regimes, as well as examples of how these tools can be integrated into water management programs.

Papers in this Special Issue are organized around three major themes:

1. Method development and testing. Research on the development of methods used to support stronger flow-ecology relationships and establish environmental water recommendations intended to maintain ecologically sustainable flow patterns for diverse biological endpoints. Papers in this theme explore the transferability of flowecology relationships (Chen \& Olden, 2018), advances in assemblage-level assessments (Cuffney \& Kennen, 2018), hydrologic modelling (Sengupta et al., 2018), development of hydraulic habitat models (Mierau et al., 2018) and advanced analytical methods (Webb, de Little, Miller, \& Stewardson, 2018), and development of biological response models that relate changes in hydrology and hydraulics to an ecological outcome or effect (Bond et al., 2018; Mazor et al., 2018).

2. Application case studies. Case studies that present application of flow-ecology response models designed to help environmental water science practitioners to better understand how alterations in streamflow and increasing levels of water scarcity affect the viability and integrity of aquatic ecosystems. Papers in this theme discuss case study examples including assessment of snowmelt conditions (Steel, Peek, Lusardi, \& 
Yarnell, 2018), identification of high risk watersheds (Zimmerman et al., 2018), and tools with improved capacity and diagnostic resolution (Monk et al., 2018; McKenna, Reeves, \& Seelbach, 2018) that can be integrated into water resource management programs at the local, state, provincial, regional and national levels.

3. Efficacy evaluation. Research and case studies that evaluate the effectiveness of environmental water programs at achieving their desired hydrological and ecological objectives or evaluating complex scenarios with multiple interacting stressors. Papers in this theme illustrate successes, challenges, and provide evaluations of how well current programs have worked (Stewardson \& Guarino, 2018); how well conceptual models have performed relative to expectations (Gendaszek, Burton, Magirl, \& Konrad, 2018); the influence of drought on flow-ecology relationships (Lynch, Leasure, \& Magoulick, 2018); and recommendations for ways to improve both the science and implementation of environmental water practice (Wheeler, Wenger, \& Freeman, 2018). This theme also includes recommendations for refinements that can improve the ability of flow-ecology tools to distinguish anthropogenic effects from changes due to climate variability (Hain et al., 2018).

Also included are several conceptual papers that actively look to the future of environmental water science and management, and provide recommendations on how this discipline needs to evolve. Topics covered include the challenges associated with evaluating legacy effects and long-term trends (Thompson, King, Kingsford, Mac Nally, \& Poff, 2018); the challenge of incorporating non-stationarity principles into ecohydrological investigations, and therefore calling for a fundamental shift in environmental water regime studies from managing for variability (of historical conditions) to managing for ecological resilience (Poff, 2018); and proposals for how scientific research might better interact with aquatic ecosystem management to more effectively translate knowledge into action and foster sensible scientific investment strategies so that collective knowledge can be translated into wise environmental water management decisions (Stoffels, Bond, \& Nicol, 2018). 
The Special Issue concludes with a synthesis of recent advances in environmental flows science and water management and a look ahead at some of the challenges still facing environmental water science practitioners (Arthington et al., 2018). Not all the challenges identified in the 2010 Special Issue of Freshwater Biology on environmental flows science and water management (Arthington et al., 2010) have been met. For example, "integrated water resource management" that incorporates ground- and surface-water regimes in support of river conservation and restoration, or "adaptive environmental management" approaches that address uncertainties and risk and facilitate follow-up interaction among scientists and managers, are only beginning to emerge. However, as greater diversity and transferability are achieved, environmental water science will continue to progress and support the needs of water managers and decision makers around the globe.

\section{ACKNOWLEDGEMENTS}

We thank David L. Strayer of the Cary Institute of Ecosystems Studies for inviting us to advance the discussion on environmental water regimes by developing a Special Issue. We earnestly thank the many environmental water practitioners who submitted thoughtful and timely papers as part of this Special Issue and David Dudgeon and Emma Boxer for their support and expertise in guiding this Special Issue through the review and publication process. Jason May of the U.S. Geological Survey provided many helpful suggestions that improved this manuscript. Etymological insights from Angela Arthington on early drafts of this paper were greatly appreciated. The use of trade, product, or firm names is for descriptive purposes only and does not imply endorsement by the U.S. Government.

\section{REFERENCES CITED}

Acreman M. C., Overton I. C., King J., Wood P. J., Cowx I. G., Dunbar M. J., Kendy E. \& Young, W.J. (2014) The changing role of ecohydrological science in guiding environmental flows. Hydrological Sciences Journal, 59, 433-450. http://dx.doi.org/10.1080/02626667.2014.886019 
Annear T., Chisholm I., Beecher H., Locke A., Aarrestad P., Coomer C., Estes C., Hunt J., Jacobson R., Jöbsi G., Kauffman J., Marshall J., Mayes K., Smith G., Wentworth R., and Stalnaker C. (2004) Instream Flows for Riverine Resource Stewardship, Revised Edition, Instream Flow Council, Cheyenne, WY, 268 p. Available at: https://www.instreamflowcouncil.org/resources/ifcpublications/instream-flows-for-riverine-resource-stewardship/

Arthington A. H. 2012. Environmental flows: saving rivers in the third millennium. University of California press, Berkeley, CA. 424 p. (ISBN 978-0-520-27369-6). Available at: http://www.ucpress.edu/book.php?isbn=9780520273696

Arthington A. H., Kennen J. G., Stein E. D. \& Webb J. A. (2018) Recent advances in environmental flows science and water management - innovation in the Anthropocene. Freshwater Biology.

Arthington, A. H., Naiman, R. J., McClain, M. E. \& Nilsson, C. (2010) Preserving the biodiversity and ecological services of rivers: New challenges and research opportunities. Freshwater Biology, 55, 1-16. http://dx.doi.org/10.1111/j.1365-2427.2009.02340.x Bond N. R., Grigg N., Roberts J., McGinness H., Nielsen D., O’Brien M., Overton I., Pollino C., Reid J. R. W., \& Stratford D. (2018) Assessment of environmental flow scenarios using stateand-transition models. Freshwater Biology, 00:1-13. https://doi.org/10.1111/fwb.13060

Bovee K. D., Lamb B. L., Bartholow J. M., Stalnaker C. B., Taylor J. \& Henriksen J. (1998) Stream habitat analysis using the instream flow incremental methodology. U.S. Geological Survey, Biological Resources Division Information and Technology Report, USGS/BRD-1998-0004. viii +131 pp. Available at:

https://www.fort.usgs.gov/sites/default/files/products/publications/3912/3912.pdf

Capon S. J. \& Capon T. R. (2017) An impossible prescription: Why science cannot determine environmental water requirements for a healthy Murray-Darling basin. Water Economics and Policy, 03, 1650037. http://dx.doi.org/10.1142/S2382624X16500375 
217 Cartwright J., Caldwell C., Nebiker S., \& Knight R. (2017) Putting flow-ecology relationships into 218 practice: A decision support system to assess fish community response to water management 219 scenarios. Water, 9, 196. http://dx.doi.org/10.3390/w9030196

220 Chen W. \& Olden J. D. (2018) Evaluating transferability of flow-ecology relationships across 221 space, time, and taxonomy. Freshwater Biology, 00:1-14. https://doi.org/10.1111/fwb.13041

222 Cuffney T. C. \& Kennen J. G. (2018) Potential pitfalls of aggregating aquatic invertebrate data 223 from multiple agency sources: Implications for detecting aquatic assemblage change across 224 alteration gradients. Freshwater Biology, 00:1-14. https://doi.org/10.1111/fwb.13031

225 Dettinger M., Udall B. \& Georgakakos A. (2015) Western water and climate change. Ecological 226 Applications, 25, 2069-2093. http://dx.doi.org/10.1890/15-0938.1

227 Estrela T., Pérez-Martin M. A. \& Vargas E. (2012) Impacts of climate change on water resources 228 in Spain. Hydrological Sciences Journal, 57, 1154-1167

229 http://dx.doi.org/10.1080/02626667.2012.702213

230 Famiglietti J., Lo M., Ho S. L., Bethune J., Anderson K. J., Syed T. H., Swenson S. C., de Linage C. 231 R. \& Rodell M. (2011) Satellites measure recent rates of groundwater depletion in California's 232 Central Valley. Geophysical Research Letters, 38, L03403.

233 http://dx.doi.org/10.1029/2010GL046442

234 Gendaszek A. S., Burton C. S., Magirl C. S. \& Konrad C. P. (2018) Streambed scour of salmon 235 spawning habitat in a regulated river influenced by management of peak discharge. Freshwater 236 Biology, 00:1-11. https://doi.org/10.1111/fwb.12987

237 Hain E. F., Kennen J. G., Caldwell P. V., Nelson S. A. C., Sun G. \& McNulty S. G. (2018) Using 238 regional scale flow-ecology modeling to identify catchments where fish assemblages are most 239 vulnerable to changes in water availability. Freshwater Biology, 00:1-18.

240 https://doi.org/10.1111/fwb.13048 
241 Hart, B. T. 2016. The Australian Murray-Darling Basin Plan: Factors leading to its successful

242 development. Ecohydrology \& Hydrobiology, 16, 229-241.

243 https://doi.org/10.1016/i.ecohyd.2016.09.002

244 Hirji R. and Davis R. (2012) Environmental Flows in Water Resources, Policies, Plans, and

245 Projects. The World Bank, Washington, DC. 189 p. Available at:

246 https://openknowledge.worldbank.org/handle/10986/2635

247 Horne, A. C., Webb J. A., Stewardson M. J., Richter B. D. \& Acreman M., editors. (2017) Water

248 for the Environment: from Policy and Science to Implementation and Management. Elsevier,

249 Cambridge MA.

250 Kendy E., Apse C., Blann K. L., Smith M. P. \& Richardson, A. (2012) A practical guide to

251 environmental flows for policy and planning-With nine case studies in the United States. The

252 Nature Conservancy. Available at:

253 http://www.oregon.gov/owrd/docs/SB839/20129 Case Studies Practical Guide.pdf

254 Le Quesne T., Kendy E. \& Weston D. (2010) The Implementation Challenge: Taking stock of 255 government policies to protect and restore environmental flows. The Nature Conservancy \&

256 World Wildlife Fund. Available at:

257 http://d2ouvy59p0dg6k.cloudfront.net/downloads/the implementation challenge.pdf

258 Lynch D. T., Leasure D. R. \& Magoulick D. D. (2018). The influence of drought on flow-ecology 259 relationships in Ozark Highland streams. Freshwater Biology.

260 Mazor R. D., May J. T., Sungupta A., McCune K. S., Bledsoe B. P. \& Stein, E. D. (2018) Tools for 261 managing hydrological alteration on a regional scale: Setting targets to protect stream health. 262 Freshwater Biology, 00:1-18. https://doi.org/10.1111/fwb.13062

263 McKenna J.E., Reeves, H. W. \& Seelbach P. W. (2018) Measuring and evaluating ecological 264 flows from streams to regions: steps toward national coverage. Freshwater Biology, 00:1-17. 265 https://doi.org/10.1111/fwb.13086 
Meybeck M. (2003) Global analysis of river systems: From earth system controls to anthropocene syndromes. Philosophical Transactions of the Royal Society of London, B 358, 1935-1955. https://doi.org/10.1098/rstb.2003.1379

Mierau D. W., Trush W. J., Rossi G. J., Carah J. K., Clifford M. O. \& Howard J. K. (2018) Managing water diversions in unregulated streams using a modified percent-of-flow approach. Freshwater Biology, 00:1-17. https://doi.org/10.1111/fwb.12985

Milhous R., Updike M. \& Schneider D. (1989) Physical Habitat Simulation System Reference Manuel - Version II. Instream Flow Information Paper No. 26. U.S. Fish and Wildlife Service Biological Report 89(16), Fort Collins, CO. Available at: https://www.fort.usgs.gov/sites/default/files/products/publications/3912/3912.pdf

Monk W. A., Compson Z. G., Armanini D. G., Orlofske J. M., Curry C. J., Peters, D. L., Crocker J. B. \& Baird D. J. (2018) Flow-velocity thresholds in Canadian rivers: A comparison of trait and taxonomy-based approaches. Freshwater Biology, 00:1-15. https://doi.org/10.1111/fwb.13030

Novak R., Kennen J. G., Abele R. W., Baschon C. F., Carlisle D. M., Dlugolecki L., Eignor D. M., Flotemersch J. E., Ford P., Fowler J., Galer R., Gordon L. P., Hansen S. E., Herbold B., Johnson T. E., Johnston J. M., Konrad C. P., Leamond B. \& Seelbach P.W. (2016) Final EPA-USGS Technical Report: Protecting Aquatic Life from Effects of Hydrologic Alteration. U.S. Geological Survey Scientific Investigations Report 2016-5164, U.S. Environmental Protection Agency EPA-822-R156-007, 58 p. Available at: https://www.epa.gov/wqc/final-epausgs-technical-reportprotecting-aquatic-life-effects-hydrologic-alteration-documents

Poff N. L. (2018). Beyond the natural flow regime? Broadening the hydro-ecological foundation of environmental flows challenges in a non-stationary world. Freshwater Biology, 00:1-11. https://doi.org/10.1111/fwb.13038

Poff N. L., Allan J. D., Palmer M. A., Hart D. D., Richter B. D., Arthington A. H., Rogers K. H., Meyers J. L., \& Stanford J. A. (2003) River flows and water wars: Emerging science for environmental decision making. Frontiers in Ecology and the Environment, 1, 298-306. https://doi.org/10.1890/1540-9295(2003)001[0298:RFAWWE]2.0.CO;2 
Poff L. N., Richter B. D., Arthington A. H., Bunn S. E., Naiman R. J., Kendy E, Acreman M., Apse

294 C., Bledsoe B. P., Freeman M. C., Henriksen J. A., Jacobson R. B., Kennen J. G., Merritt D. M.,

295 O’Keeffe J. H., Olden J. D., Rogers K., Tharme R. E. \& Warner A. (2010) The ecological limits of 296 hydrologic alteration (ELOHA) - A new framework for developing regional environmental flow 297 standards. Freshwater Biology, 55, 147-170. http://dx.doi.org/10.1111/j.1365$\underline{2427.2009 .02204 . x}$

Poff N. L. \& Zimmerman J. K. H. (2010) Ecological responses to altered flow regimes-A literature review to inform the science and management of environmental flows. Freshwater Biology, 55, 194-205. http://dx.doi.org/10.1111/j.1365-2427.2009.02272.x

302 Richter B. D. (2014). Chasing Water - A Guide for Moving from Scarcity to Sustainability. Island Press, (ISBN: 9781610915380). Available at: https://islandpress.org/book/chasing-water

304 Richter B. D., Davis M. M., Apse C., and Konrad C. 2011. A presumptive standard for 305 environmental flow protection. River Research and Applications, 28, 1,312-1,321.

306 http://dx.doi.org/10.1002/rra.1511

307 Sengupta A., Stein E. D., McCune K. S., Mazor R. D., Adams S., Bledsoe B. P. \& Konrad C. (2018)

308 Tools for managing hydrological alteration on a regional scale: Estimating changes in flow

309 characteristics at ungauged sites. Freshwater Biology, 00:1-17.

$310 \quad$ https://doi.org/10.1111/fwb.13074

311 Steel A., Peek R. A., Lusardi R. A. \& Yarnell S. M. (2018) Associating metrics of hydrologic

312 variability with benthic macroinvertebrate communities in regulated and unregulated

313 snowmelt-dominated rivers. Freshwater Biology, 00:1-15. https://doi.org/10.1111/fwb.12994

314 Stewardson M. \& Guarino E. (2018) Basin-scale environmental water delivery in the Murray-

315 Darling, Australia: A hydrological perspective. Freshwater Biology, 00:1-17.

316 https://doi.org/10.1111/fwb.13074

317 Stoffels R. J., Bond N. R. \& Nicol S. (2018) Science to support the management of riverine flows.

318 Freshwater Biology, 00:1-15. https://doi.org/10.1111/fwb.13061 
Thompson R. M., King A. J., Kingsford R. M., Mac Nally R. \& Poff N. L. (2018) Legacies, lags, and long term trends: Effective flow restoration in a changed and changing world. Freshwater Biology, 00:1-10. https://doi.org/10.1111/fwb.13029

Trenberth K. E., Overpeck J. T. \& Solomon S. (2004) Exploring drought and its implications for the future. Eos, 85, 27. http://dx.doi.org/10.1029/2004EO030004

Veldkamp T. I. E., Eisner S., Wada Y., Aerts J. C. J. H. \& Ward P. J. (2015) Sensitivity of water scarcity events to ENSO-driven climate variability at the global scale. Hydrology and Earth System Sciences, 19, 4081-4098. https://doi.org/10.5194/hess-19-4081-2015

Vörösmarty C. J., Mclntyre P. B., Gessner M. O., Dudgeon D., Prusevich A., Green P., Glidden S., Bunn S. E., Sullivan C. A., Reidy Liermann C. A. \& Davies P. M. (2010) Global threats to human water security and river biodiversity. Nature, 467, 555-561.

http://dx.doi.org/10.1038/nature09440

Webb J. A., de Little S. C., Miller K. A. \& Stewardson M. J. (2018) Quantifying and predicting the benefits of environmental flows: Combining large-scale monitoring data and expert knowledge within hierarchical Bayesian models Freshwater Biology, 00:1-13.

\section{https://doi.org/10.1111/fwb.13069}

Webb J. A., Miller K. A., King E. L., Little S. C. de, Stewardson M. J., Zimmerman J. K. H. \& Poff N. L. (2013) Squeezing the most out of existing literature-A systematic re-analysis of published evidence on ecological responses to altered flows. Freshwater Biology, 58, 2439-2451. http://dx.doi.org/10.1111/fwb.12234

Webb, J. A., Watts, R. J., Allan, C. \& Conallin, J. C. (2018) Adaptive management of environmental flows. Environmental Management, 61, 339-346.

http://doi.org/10.1007/s00267-017-0981-6

Wheeler K., Wenger S. J. \& Freeman M. C. (2018) States and rates: Complementary approaches to developing flow-ecology relationships. Freshwater Biology; 00:1-11.

https://doi.org/10.1111/fwb.13001 
345 Williams A. P., Seager R., Abatzoglou J. T., Cook B. I., Smerdon J. E. \& Cook E. R. (2015),

346 Contribution of anthropogenic warming to California drought during 2012-2014. Geophysical

347 Research Letters, 42, 6819-6828. http://dx.doi.org/10.1002/2015GL064924

348 Williamson T. N., Lant J. G., Claggett P. R., Nystrom E. A., Milly P. C. D., Nelson H. L., Hoffman S.

349 A., Colarullo S. J., \& Fischer J. M. (2015) Summary of hydrologic modeling for the Delaware River

350 Basin using the Water Availability Tool for Environmental Resources (WATER). U.S. Geological

351 Survey Scientific Investigations Report 2015-5143, 68 p. Available at:

352 http://dx.doi.org/10.3133/sir20155143

353 Zimmerman, J. K. H., Carlisle, D. M., May J. T., Howard J. K., Klausmeyer K. R., Brown L. R. \& 354 Grantham T. (2018) Patterns and magnitude of flow alteration in California, USA. Freshwater 355 Biology, 00:1-15. https://doi.org/10.1111/fwb.13058

\section{LIST OF FIGURES}

Figure 1. A representative subset of federal and provincial governments showing approximate

360 inception and length of environmental water science programs (a) and cumulative growth in 361 number of environmental water science programs in the US compared to programs worldwide 362 (b). Information presented in this figure was obtained from numerous published sources 363 including The Nature Conservancy, and a series of governmental reports from Australia, 364 Canada, China, the European Union, South Africa, the United States, as well as several 365 individual U.S. States. 


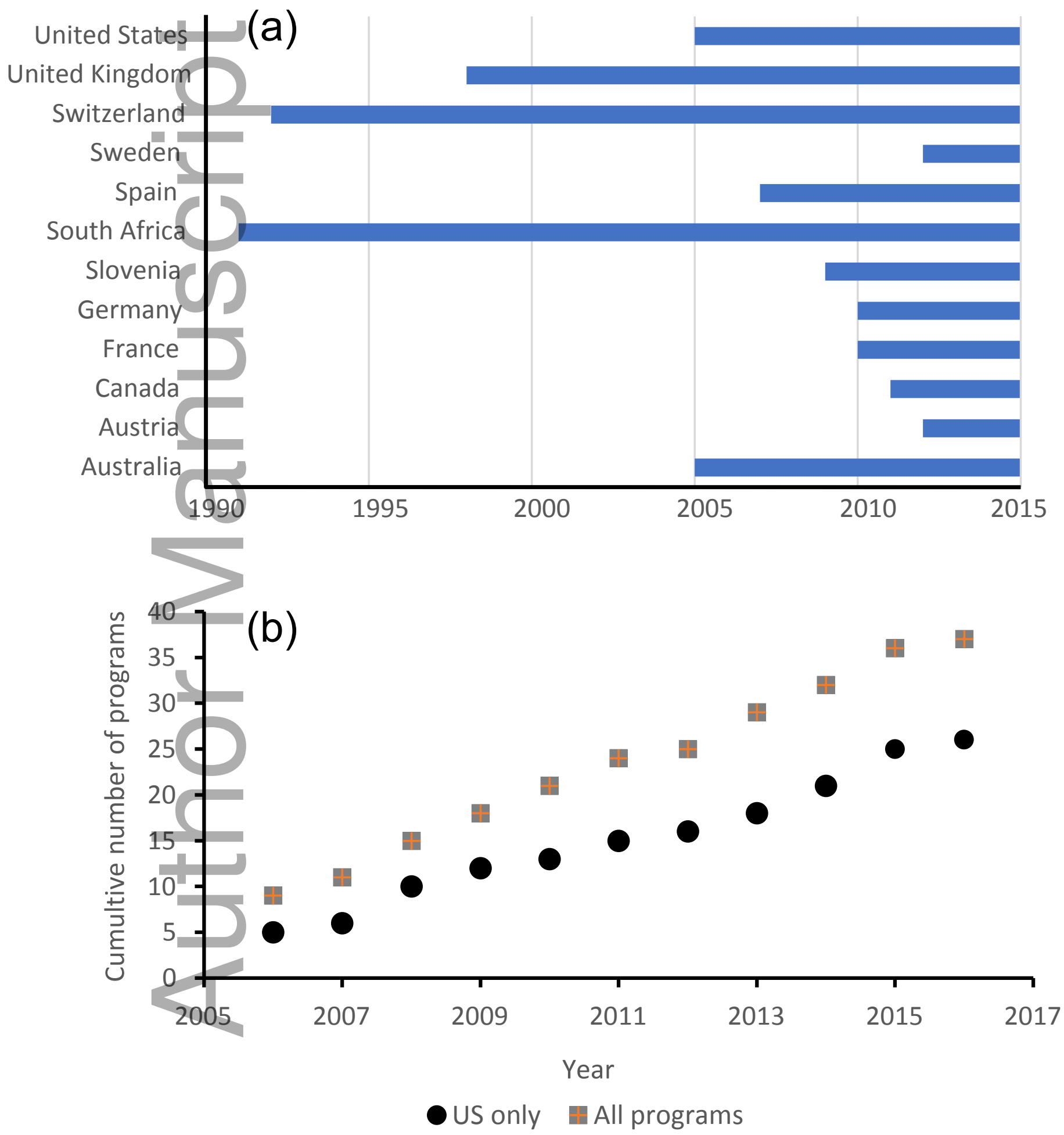

This article is protected by copyright. All rights reserved 


\section{University Library}

\section{- M M N E R VA A gateway to Melbourne's research publications}

Minerva Access is the Institutional Repository of The University of Melbourne

Author/s:

Kennen, JG;Stein, ED;Webb, JA

Title:

Evaluating and managing environmental water regimes in a water-scarce and uncertain future

Date:

2018-08-01

Citation:

Kennen, J. G., Stein, E. D. \& Webb, J. A. (2018). Evaluating and managing environmental water regimes in a water-scarce and uncertain future. FRESHWATER BIOLOGY, 63 (8), pp.733-737. https://doi.org/10.1111/fwb.13104.

Persistent Link:

http://hdl.handle.net/11343/284321 